Article

\title{
Systems over Service: Changing Systems of Inequality through Congregational Political Engagement
}

\author{
Rebecca Sager \\ Sociology Department, Loyola Marymount University, Los Angeles, CA 90045, USA; E-Mail: rsager@Imu.edu
}

Submitted: 7 February 2018 | Accepted: 14 April 2018 | Published: 22 June 2018

\begin{abstract}
The role of religious groups in changing inequality has usually been a bottom up approach. Whether it was serving meals to the needy or sheltering the homeless, the vast majority of religious groups have addressed problems of inequality, not by addressing the causes of hunger and homelessness, but rather by offering assistance to those already in need. Rarely have religious groups become engaged in explicitly political activities that challenge structures that create large scale inequality. In this article, I examine the first state level efforts by LA Voice, a congregation-based community group that has worked to ameliorate inequality through political organizing with churches in largely poor minority communities throughout Los Angeles. Drawing on extensive qualitative data from field research and interviews during their first campaign season in 2012, I examine how these religious groups organized around a controversial political issue-an important move away from their traditional community-based organizing-and how their understandings of faith informed this work. Specifically, LA Voice helped pass a state-level initiative that directly challenged systems of inequality; Proposition 30, which raised taxes on the wealthy to fund public education. This political work highlighted long known internal struggles between congregation members who fought these actions and those who recognized the need in their communities and enthusiastically took up this work. This article ends with a discussion of how these early efforts resulted in further engagement by other member congregations.
\end{abstract}

\section{Keywords}

congregations; inequality; politics; religion

\section{Issue}

This article is part of the issue "Complex Religion: Intersections of Religion and Inequality", edited by Melissa J. Wilde (University of Pennsylvania, USA).

(C) 2018 by the author; licensee Cogitatio (Lisbon, Portugal). This article is licensed under a Creative Commons Attribution 4.0 International License (CC BY).

\section{Introduction}

The role of religious groups when it comes to income inequality has always been a complicated one (Wilde \& Glassman, 2016). While in some cases religious groups have made efforts to help reduce inequality through a variety of political initiatives dealing with immigration (Yukich, 2013), healthcare (Wood, 2002), and labor rights (Fisher, 1989), this work is not the norm. Most of the time religious groups have focused on aiding people in need, rather than fixing the underlying reasons why people are in need (Chaves, 2004). Even though some religious groups have made efforts to limit inequalities, religion itself can be often perceived as supporting systems that enable economic and racial inequalities to thrive (Wilde \& Danielson, 2014; Wilde \& Glassman, 2016). Therefore, few religious groups are interested in challenging these very systems. This means that whether it is serving meals to the needy or sheltering the homeless, most religious groups have addressed problems of inequality not by addressing the causes of hunger and homelessness, but rather by offering assistance to people harmed by systems of inequality (Chaves \& Tsitsos, 2001).

In this article, I examine how one organization, LA Voice, a congregation-based community organizing group, attempted to change this trend by creating large scale political change through political organizing around 
a statewide ballot initiative. Specifically, in 2012 six LA Voice member congregations began high intensity political organizing requiring large numbers of congregational volunteers around Proposition 30, a state-wide ballot initiative that aimed to address issues of inequality by increasing funds for public education through a tax increase largely on the wealthy. Drawing on qualitative data from field research and interviews with LA Voice and their member congregations between 2012-2015, I examine how these six congregations organized around this issue, a significant departure from their traditional community-based organizing.

In 2012, four Catholic congregations, along with one protestant and one Jewish group that participated at a lower intensity, engaged in extensive high demand political organizing for Proposition 30, volunteering thousands of hours phone-banking, doing voter registration and getting out the vote efforts. In this article, I examine how these congregations became engaged; focusing on the role of religious and lay leadership in shaping the political engagement of their congregations, how their religious views connected with political activism, and how these congregations successfully worked around unwilling members. These early efforts later resulted in expanded political work at many more LA Voice member congregations, as well as new impactful policies for California.

\section{Previous Research}

Congregations and religious groups have a long history of helping the poor. Whether it's Catholic Charities assisting the homeless, or Lutheran Social Services establishing education programs for underserved communities, religious groups in the United States have long carried the mantle to aid those in need (Chaves, 2004; Chaves \& Tsitsos, 2001). While these religious groups offer aid to the needy, they rarely engage in the types of political activities that would change the systems that create such staggering need in the first place (Chaves \& Tsitsos, 2001; for recent exceptions see: Yukich, 2013; Wood, 2002; Wood \& Fulton, 2015). In the present section I address why this may be occurring.

\subsection{Congregations and the Politics of Inequality}

So why do religious congregations tend to shy away from the type of political work that changes the systems of inequality? First, it is a far greater challenge to change systems of inequality than it is to offer food or shelter. Most congregations offer some sort of assistance to the poor- whether it is through soup kitchens or homeless outreach-but very few execute the types of political activism necessary to sway the need for these efforts. In their work on religion and social services, Chaves and Tsitsos found that $58 \%$ of congregations, containing $78 \%$ of attendees offer some kind of social service (Chaves \& Tsitsos, 2001, p. 668); however, most do not engage in polit- ical outreach. In his 2004 book on congregations, Mark Chaves found that few congregations engage in any kind of political work, with $58 \%$ of congregations not engaging in any type of political activity (Chaves, 2004, p. 108); of those that do, only $9 \%$ of congregations engage in voter registration or a meeting about a policy, and fewer (about 4\%) engage in the type of continuous long-term high intensity political work that is required to make significant political impacts (Chaves, 2004). Thus, while the majority of congregations are willing to do some kind of activity to help serve the poor, very few are doing the type of work LA Voice's congregations were engaged with-namely, large scale systematic political work to make sure there are fewer poor people to begin with.

There are several reasons for this focus. First, doing the type of community-based outreach necessary to change social systems requires a significant amount of time, energy, and expertise, something most congregations simply do not possess (Chaves, 2004; Chaves \& Tsitsos, 2001). Most congregations are small in size, with many having only part-time or no professional staff at all and lack the resources or know how to do the kind of work that would be required to address political systems that create inequality (Chaves \& Tsitsos, 2001). Additionally, other research has shown that many religious actors and congregation members prefer not to have politics as part of their congregations and act on their own (Wuthnow, 2002). One other problem for congregations becoming involved in politics around systems of inequality is that religious actors often view poverty as an individual problem (Emmerson, Smith, \& Sikkink, 1999; Hunt, 2002), which makes organizing around systems of inequality particularly challenging (Wilde \& Glassman, 2016). The congregations in this study had to figure out a way to deal with these issues.

Finally, while we do know important information about congregational political activity around inequality, especially in the local arena (Wood, 2002; Wood \& Fulton, 2015), there is still a lot to be learned about congregations and their political work (Wilde \& Glassman, 2016). What we do know is that many congregations are involved in at least some nominal level of politics (Chaves, 2004), can be the backbone of social movements (PattilloMcCoy, 1998), are often strongly engaged in community organizing and local politics (Lichterman, 2008; Wood, 2002), and vary greatly in the types of political activities they are involved with (Chaves \& Beyerlein, 2003). For example, we know that conservative Christian churches are more likely to distribute conservative Christian voter pamphlets and that Catholic churches are more likely to march or protest, likely about abortion (Chaves \& Beyerlein, 2003), but also around immigration (Yukich, 2013) or workers' rights (Fisher, 1989). Additionally, we know that, historically, black churches have been strongly engaged in civil rights movements offering important resources such as leadership, meeting spaces and engaged members (Pattillo-McCoy, 1998). Finally, we also know that congregations have interacted in politics in a num- 
ber of ways, based not only on their religious beliefs, but because of their place in the racial and class hierarchy (Wilde \& Glassman, 2016). For instance, white Protestant congregations in the 1930s and '40s were the loci for birth control reform based both on their belief in the social gospel and fears of racial suicide, or fears that white Protestants were being overrun by religious minorities from southern and eastern Europe (Wilde \& Danielson, 2014). This means that the type and reasons for political activism in congregations are varied, and not always simply because of their underlying theology.

While we know a great deal about religious organizing in politics, there is still much we do not know about congregations and political organizing including how congregations become involved in political campaigns around issues of inequality, how they negotiate class and racial tensions that become apparent in this work, or if their work might impact other congregations in a similar network. Since only $4 \%$ of congregations take on this high level of engagement, understanding the LA Voice congregations and their engagement offers a chance to better understand this rare work. Additionally, while we do not know how much political activity is related to systematic issues of inequality; we do know that since conservative churches almost always get involved in conservative causes (Chaves \& Beyerlein, 2003), we can then infer that the chances of congregations becoming involved in changing political systems that produce inequality is very small. Understanding how the LA Voice congregations actively engaged in these issues helps shed some light on these questions.

\section{Data and Methods}

From April 2012 to March 2015, field research and indepth interviews with key informants were conducted during two political campaigns with LA Voice. In this article, I focus on the first of these campaigns, Proposition 30. LA Voice is part of the PICO National Network (originally the People Improving Communities through Organizing), a faith-based community-organizing group founded in 1972. Since 1972, PICO has grown to over 150 affiliates in fifty cities throughout the United States; LA Voice is one of these affiliates that works on its own organizing efforts in conjunction with PICO's state and federal offices. In 2012, LA Voice had nineteen (19) member congregations from a variety of theological and racial-ethnic backgrounds. During this time, much of LA Voice's organizing efforts were conducted in conjunction with PICO's state office-PICO California. Fieldnotes were taken at LA Voice events, but the work being done on these initiatives was often a tandem effort by both LA Voice and PICO California.

The first phase of data collection occurred in 2012, during LA Voice's organizing around Proposition 30. Field research was conducted at various events including strategy meetings, organizing meetings, and canvassing for voters. Sixteen (16) in-depth interviews were then conducted with participating ministers, congregation-based organizers, and secular organizers. Questions were asked about their organizing, congregational engagement, religious beliefs, and organizing history. This article analyzes these data about congregational organizing for Proposition 30 .

\section{Changing Inequality through Congregational Political Engagement}

Until their foray into electoral politics in 2012, LA Voice congregations had worked on community organizing campaigns. This meant that LA Voice congregation worked on local issues that were important to member congregations such as ensuring there was a grocery store in an undeserved neighborhood, affordable housing near member congregations, lobbying city council members for better wages, or working with police to get rid of a drug house in the neighborhood. Their move into doing state level politics that included issues such as voter registration, informing voters about Proposition 30, and getting out the vote during the election, were significant departures from their usual brand of organizing, which relied on long-term, community-focused campaigns rather than state-wide, short-term high intensity voter drives. While PICO California had long been involved in state level political outreach, this work involved attempting to influence individual legislators to pass specific bills, not working to pass state level voter initiatives (Wood, 2002). While this earlier political work by PICO California relied on local level affiliates like LA Voice to do supportive local work (Wood, 2002), local level affiliates were not specifically involved in doing the type of higher level politics until Proposition 30. This meant that, for both PICO and LA Voice, helping to pass Proposition 30 was a very different way to create political change.

So how did these congregations work to change the politics of inequality in California? I argue that the answer is twofold. First, the congregations were able to harness resources outside of their own organizations. LA Voice and PICO helped member congregations by partnering with experienced politically active secular groups at both the state and local level, leveraging resources and giving them access to knowledge and technology that that they would not have had otherwise (Tarrow, 2011). ${ }^{1}$ These resources, including phone banking equipment, voter lists, and training on getting out the vote; these were shared with congregations allowing them to leverage their most important resources, congregation members as volunteers. This meant that the issues often encountered by congregations, such as lack of knowledge or technology (Chaves \& Tsitsos, 2001), were overcome because the LA Voice congregations were able to rely on external resources to meet these needs.

Second, while LA Voice had to harness outside resources for some of their work, similar to previous work

\footnotetext{
$\overline{1}$ I expand on these relationships more deeply in a separate work with two co-authors (Fulton, Sager, \& Wood, 2015).
} 
by religious groups in political activism (Pattillo-McCoy, 1998; Wood, 2002; Yukich, 2013), they were able to rely on internal resources for much of their political engagement. So how did these congregations engage in the fight for Proposition 30? What were the actions they took? In this article I argue that there were three ways the congregations became involved in the fight for Proposition 30. First, their religious leadership brought ideas about political organizing into congregations. Second, to engage willing congregation members, religious and lay leaders had to make the connections between their members religious beliefs, personal struggles and the political goal of the proposition. Finally, because of class tensions that became apparent during Proposition 30, religious leaders then used a targeted approach when bringing in these political battles to the congregation. Through this work they were successfully able to do significant amounts of voter outreach and show other LA Voice congregations that this kind of political engagement was not only meaningful, but made a large scale difference.

\subsection{Religious Leaders and Congregational Engagement}

Research shows that leaders of a congregation have significant power and are often key to successful political or community engagement in congregations (Carroll, 2006). The leaders of these LA Voice congregations were key organizers in the political engagement of congregations around Proposition 30. As one lay leader, Michelle, succinctly noted:

It really takes the clergy, the pastoral leader of that parish or congregation to push that forward and be really present in the beginning....and encouraging them to take a look at this with an action plan that's more baby steps, as opposed to trying to see the whole elephant.

In other words, the religious leader was key to the congregation seeing the role they could play in the election, even if at the beginning it appeared daunting. Religious leaders who truly believed in the initiative were able to harness the power of their congregation to successfully work on the initiative. Bianca, one of the lay leaders at a different congregation, described how the priest at her congregation made the push for Proposition 30 something he regularly discussed during his sermons:

Father John was very instrumental, I believe, in making announcements and making sure that the congregation, both in Spanish and in English and Tagalog, knew the importance of this proposition, and...that whatever propaganda was being put out there to divert the reality of this from the people, they would know what to expect. So he has always been very instrumental in something that he feels a passion for.
The leadership pushed the idea of being involved in the campaign because they truly believed in it and were willing to counter myths or other falsehoods.

The religious leaders of these congregations saw the initiative as part of their mission. Father James, one of the priests I spoke with discussed bringing up these political issues from the pulpit as "conversions" and that he saw his role as much more than a person who gives a sermon every Sunday:

I think my role is to tell stories and help people see the real dignity of people despite their finances because I actually think that most people really do want to do the right thing, and if you just help people to see the dignity of human beings....I'm allowing those stories to help convert them. And by conversion I mean just soften their hearts, make them want to help in some way. I think that's part of my role. I think the Jesuits, if we're doing our jobs right, we should have our foot in a lot of different doors. We should have one foot with the poor and one foot with the rich. We should have one foot in politics and one foot in religion. We should have one foot at city hall and one foot at Skid Row. I think that's what we should be doing, and I think people look to us to do that.

The commitment by religious leaders to bringing this issue to their congregations cannot be overstated. It was not just bringing up these issues in mass, but also allowing organizers from LA Voice to come into the church and make announcements and get recruits. As Bianca explained:

Father John made the announcements at the mass, which is really great whenever something like this happens. He made the announcements that we were going to have our first meeting, and he explained what it was about. He had a mass welcoming LA Voice. From there we had our meeting. The first time we probably had over 150 to 200 people.

Without allowing organizers to come into churches and without the continuous push from the pulpit, the congregations would not have expanded their role as something more than a congregation that helps the poor in their own community, rather than a congregation that works so that the system creates fewer poor people.

Religious leaders not only spoke from the pulpit, but they also brought Proposition 30 to the forefront in what are called one on ones, or individual meetings with congregation members. Father James, whose congregation is in a poor neighborhood in east LA, described the intense process of these one on ones and how they helped to build a sense of activism within the congregation because they owned the issues that they were going to work on over time. 
The first thing we did was a one-on-one campaign. I think we did three hundred, one-to-ones. Three hundred conversations with people. We wrote the results of them on these stars. The questions were something like, 'What's your dream? What do you think needs to be done in this community?' We wrote the results of that in brief one- or two-word answers on these gold stars made out of paper, and then we had a big piece of blue paper on the front of the church by the altar, and we taped them to that, like, 'These are our stars that are going to lead us to some new place'.

This direct involvement was especially important in getting volunteers out. In one of the organizing meetings I attended the organizers noted that when the religious leaders became involved in campaigning it helped motivate the whole church. Quoting Bianca: "It was really fun. We made these events [voter drives] into community days and we all went out with priest to campaign. After that people wanted to do it again". At one of the Catholic congregations, I made several trips through the neighborhood to register voters, but it was when I went with the congregation's nun that the best results were achieved. When she would walk with us, people would come out of their houses and say "hello"; otherwise we did not get such a friendly reception. By becoming engaged at the pulpit and in the streets, religious leaders were instrumental in creating congregation-wide engagement.

\subsection{Framing Religious Values as Political Values}

It was not just who discussed these issues, but how they discussed them. Telling the congregation that they had to be involved in politics or moving too soon into a political discussion, was not going to work. Previous work on religion and political engagement has shown that connecting religious beliefs with political actions helps bolster congregation engagement (Yukich, 2013). This means that for work on an issue such as Proposition 30, politics needed to be introduced as part of the religious underpinnings of the church-in other words, you have to start with the values, then move onto the politics. One of the organizers of the Jewish group working on Proposition 30, Adam, discussed how he saw this happen in other congregations that were also working on Proposition 30:

You can't start with politics. You have to start with values and justice. The pastor at Our Lady (name removed) has become a huge leader on a bunch of issues and is apolitical to conservative. He's not motivated by those things, but he is motivated by values and the stories that people have.

In other words, the politics were secondary to the religious values. The values were how the leaders connected their congregations to this new type of political work. Eric, pastor in one of the most conservative churches in the group, described how he took the religious symbolism around him and the religious stories in churches to help parishioners make these connections.

It's nice to see a sentimental poster of Jesus bouncing children on his knee, and the caption reads, 'Let the little children come unto me, and don't forbid them, for such is the kingdom of heaven', that's a beautiful image, but when we want to say, 'OK, not making the little children suffer means giving them adequate education and safe neighborhoods and healthy food, this is what it means to step up for the little children', I try to explain it to them in theological terms that they'll understand.

By explaining the religious underpinnings of working on Proposition 30, the religious leaders could create space for their congregants to see why they should become involved in this work. One of the LA Voice leaders, Richard, noted that being religious and having a certain set of values would lead to more "openness" to the kinds of teachings about these political initiatives. Creating this openness by bringing in politics was something that Father James noted that many congregation members desired:

I love talking about this stuff at Sunday masses, including it in the homily and the liturgy. That's what I bring, I can drive the point home pretty well through the course of the liturgy.... can help people have a more spiritual reasoning behind why they would do something like vote for Prop. 30 or work for Prop. 30 or work for social justice. You could almost feel people in the room go, 'Ah!' like a sigh of relief when I said, 'The minute that Jesus puts this child in front of us, we become political. We have to realize that Jesus was being political and calling on us to be political, too'. At one mass, someone was like, 'Oh, finally someone said the truth!' So I think it's that that I can bring.

This move to bringing in discussion of a specific proposition that addressed inequality and the pain members were feeling into multiple sermons, was in many ways a radical move, but for some church members it was also a welcome move. In one of the organizing meetings I attended, a young Latino woman who belonged to one of the churches organizing for Proposition 30 told the story about how she had to stay at community college for much longer than she had planned because there were not enough classes being offered: "I couldn't register for the classes I needed. There was only one class and I had to fight with 30 other students for one spot; it really sucks to have to keep fighting". This means that the push by clergy for the congregation to fight for Proposition 30 matched the needs of many members of the congregation. Through their sermons, they created a space where the stories of congregation members were welcomed. As one religious leader noted: "We just kept telling stories and doing one-to-ones in our congregation, finding out 
where people's pain was at..." By finding out where their pain was at, they could then talk about how the issues they were working on could at least help resolve some of the pain they were feeling. By becoming involved in political projects that matched their religious goals and congregations needs, these congregations became powerful political organizations.

\subsection{Overcoming Congregational Obstacles}

All the congregations that became involved in Proposition 30 faced pushback from wealthier and more politically conservative congregants. While these congregations had been involved in previous local level efforts to help their communities, Proposition 30 was about raising taxes on the wealthy, including members of the congregations. This meant there were some wealthier congregation members that felt threatened by this political work, creating challenges for organizers (Wilde \& Glassman, 2016). Similar to what Yukich (2013) found in her work on the New Sanctuary Movement, in some ways this meant that organizers actually had to work for change on two fronts: the political and the religious one. As one LA Voice organizer, Sherrie, noted: "With the low income congregations it just made sense, but when we were talking to more middleclass communities it was more challenging". While congregation members may say they want to help the poor, this does not mean they want to make changes to the system that benefits them in order to do so (Wilde \& Glassman, 2016). To deal with these members, religious leaders developed strategies to go around them or counter their objections. Sister Marie, one of the religious leaders I spoke with, discussed how she would not talk about this issue at a certain mass, since she knew there would be people who would object:

I have a section of the community that are Republican and wealthy. They were not in favor of it, and for that reason I didn't talk about it much from the pulpit at the 10 o'clock mass, because that's the mass that most of my Republicans go to. We did it outside the church, asked people to be part of it and participate.

For the religious leaders, pushback from congregation members was sometimes a challenge. People would come up to them after church and complain about the politics, but because they were dedicated they would brush these criticisms to the side or work to convince them that this was the right move. Michelle explained:

We also had the challenge of-and I can speak for some of the clergy leaders-because at one of our forums we discovered that we do have some pretty affluent, wealthy parishioners who preferred another proposition, or preferred neither of these, neither Prop. 30 or Prop. 38. They would test us. But eventually we saw that the true identity of the congregation in terms of the community and in terms of com- munity leaders. After those final pushes, I think those who were against it before were in line with us.

To overcome these objections, Father John discussed how he tailored his sermons depending on his audience, so he knew he was reaching the people who would want to be involved, while not reaching the people who would push back.

My sermons talked about Prop. 30. I made it a very big focal point in Spanish, at our 5 o'clock youth mass. The reason I went specifically with them is because they are the ones that are voting.... f found out parishioners in English were much more receptive to being involved in sustainable issues, land use, circulation, they were much more involved proactively in trying to better the city. So you've got to pick and choose how you do your fights.

Knowing your audience took an engaged religious leader. Pastor Eric discussed his interaction with getting his church board to agree to become involved. While the board eventually agreed with him to become involved in Proposition 30, it was not easy because of their concern that it would divide the congregation, a reasonable concern given the nature of the debate:

The board was a little hesitant. We voted as a church board to be involved up to a certain point and then we went back and they said, 'OK, let's be involved all the way'....The risk is that it splits people, divides the church along political lines.....And when we had those conversations, I would say, 'I agree, I agree, I agree, but right now, if we don't pass this measure, the kids are going to have a shorter school year next year and teachers are going to be let go and the classrooms are going to get bigger and community colleges are going to get even harder to book classes in. This is what's going to happen starting in January'.

Engaged religious leaders targeted the right audiences within the churches, avoided potentially contentious audiences, and then worked to convince those who were not on board. These various strategies meant that while the path to being politically active was sometimes challenging, the churches that did become engaged were willing to continue this involvement in the next election for Proposition 47, a state wide criminal justice reform initiative.

\subsection{Congregational Political Success}

In their campaign to pass Proposition 30, LA Voice congregations had truly impressive results: they had 9,290 conversations with voters, identified 7,242 supporters of Proposition 30, and got 5,149 voters turned out to vote "yes" for the initiative-a $71 \%$ response rate from contacted voters. Through phone-banking, door knocking, 
and thousands of volunteer hours, they got a significant number of voters to the polls to help pass Proposition 30. Father John, who was very engaged, discussed how his congregation worked hard over the summer and fall to help turn out voters:

Education here has been poor historically...so we started doing campaigning that summer, started doing some telephone-banking with a new group we just formed. We worked around the clock. We had adults, high school students involved, and we had leaders of our youth ministry. It was really a roundabout effort. We probably worked on close to seven hundred voters that became active. We went through the inactive list. By the time election day hit, seven hundred voters went from inactive to active. It was amazing in the city itself. I think in a municipal election, less than 4,000 people vote.

In a town where only 4,000 people vote, one congregation turned out 700 new voters, or an almost $20 \%$ increase in the number of active voters. This meant that, in the end, Proposition 30 passed with $55.37 \%$ of the vote. Soon after, community colleges began adding more classes (Rivera, 2012).

One other result was also clear for these congregations; the victories that they had helped create in 2012 made these congregations feel efficacious and therefore more willing to engage in future political activism. After the Proposition 30 win the congregations had the self-perception that they could alter the political realities through their own organizing in a world that often seemed so hopeless. They saw vulnerabilities in the system and took advantage of the political opportunities that were presented (Meyer, 2004). As Father James noted:

It was the first time we did it. And I have to say, I'm really grateful we did it. I felt better as a person that we got involved in this instead of just sitting at the sidelines and watching other people be involved. I felt like we were truly putting our faith into action.

Religious leader Sister Marie, who became strongly involved in her churches work, remembered how excited she was when she saw how many people had come out to vote, something that greatly surprised her and made her realize how important it was that the church becomes involved in politics; for her, you could not separate the two.

The lines were out the door, and a lot of them were our parishioners, Hispanic, in line...it made a huge difference. And walking the streets and saying hi to people and meeting them was great. I enjoyed it, and I think the people did, too, even the people in their homes, seeing the church take a stand on something. And we've taught that politics is part of the church, we've talked about this with them, that politics is not separate from the church, that you are asked to be a citizen and therefore you need to be an educated citizen and know what's right.

The challenges they had faced felt surmountable and the end result was a sense that they could make even greater change: "We've already showed that it can work", Bianca said, "I really do believe that since Prop. 30 passed we've got one foot in the door". The organizers I spoke with felt that the challenge, for the most part, was getting people to realize that they could make a difference and seeing others make a difference. As Sherrie, an organizer, put it: "So a lot of people have to become very brave and take some risks, and then learn that they're actually okay". This bravery was contagious and spread to other network congregations.

After the 2012 election, six additional congregations became involved in the fight for Proposition 47 in 2014, a statewide ballot initiative which aimed to limit the number of people in prison-another way that systematic inequality is perpetuated-by limiting the number of crimes that could be charged as felonies. It passed by $59.61 \%$. An additional three other congregations became active in the 2016 elections and campaigned on several ballot initiatives aimed at tackling affordable housing and public transportation, both of which passed. All of these congregations in the LA Voice network are planning on continuing this state-level political engagement in 2018.

\section{Conclusion}

The congregations in this study became engaged in a type of political organizing that was very new to them. To take on passing a state-level initiative that would increase taxes on the wealthy, including members of their own congregations, required an intense amount of work by the LA Voice organizers, resources from PICO, LA Voice and other secular organizations, strongly involved and committed clergy, and work within their own congregations to negotiate opposition. Through telling stories, maneuvering around potential problems in the congregations, and linking the pain of the parishioners with the political change, the congregations in this study became politically savvy organizations that were able to make a difference in challenging a system that often perpetuates inequality. LA Voice organizer Sherrie noted that by getting congregations to think about systems versus service, these congregations were now able to start changing the realities of what life looked like for their members and society at large:

Congregations who are deeply worried about homelessness, for example, can talk about homelessness till they're blue in the face, but if they're never talking about mental healthcare and affordable housing we're just going to be feeding people for the rest of our lives....And so I think congregations need to not be 
afraid to engage in those bigger system level changes and to know that that's really all part of transforming the world.

The fight to alter systematic inequality was something congregations and their leaders began to view as no longer optional-their religion called them into action and helped direct their work. By shifting understandings of what a church could and could not do when it comes to politics, the politically active congregations within the LA Voice network, created a new understanding within their congregations about what was possible for them to accomplish when it came to systematic political change. This model of religious political success then spread to other member congregations and to new initiatives that challenged inequality. If congregations take up political issues which address systems that perpetuate inequality they can create broader political changes.

\section{Acknowledgements}

I would like to thank the Louisville Institute and Loyola Marymount University for their generous funding of this project. I also want to thank LA Voice for the continuous cooperation and access that allowed me to complete this project.

\section{Conflict of Interests}

The author declares no conflict of interests.

\section{References}

Carroll, J. (2006). Gods potters: Pastoral leadership and the shaping of congregations. Grand Rapids, MI: William Edermans Publishing.

Chaves, M. (2004). Congregations in America. Cambridge, MA: Harvard University Press.

Chaves, M., \& Beyerlein, K. (2003). The political activities of religious congregations in the United States. Journal for the Scientific Study of Religion, 42(2), 229-246.

Chaves, M., \& Tsitsos, W. (2001). Congregations and social services: What they do, how they do it, and with whom. Nonprofit Voluntary Sector Quarterly, 30(4), 660-683.

Emmerson, M., Smith, C., \& Sikkink, D. (1999). Equal in Christ, but not in the world: White conservative
Protestants and explanations of black-white inequality. Social Problems, 46(3), 398-417.

Fisher, J. (1989). The Catholic counterculture in America: 1933-1962. Chapel Hill, NC: University of North Carolina Press.

Fulton, B., Sager, R., \& Wood, R. (2015). Secular religious alliances in political organizing. Paper presented at the Association for the Sociology of Religion, annual meeting, Chicago, IL.

Hunt, M. (2002). Religion, race/ethnicity, and beliefs about poverty. Social Science Quarterly, 83(3), 810-831.

Lichterman, P. (2008). The civic life of American religion. Stanford, CA: Stanford University Press.

Meyer, D. (2004). Protest and political opportunities. Annual Review of Sociology, 30(2004), 125-45.

Pattillo-McCoy, M. (1998). Church culture as a strategy of action in the black community. American Sociological Review, 63(6), 767-784.

Rivera, C. (2012). Prop. 30: Community colleges will add classes with funding boost. Los Angeles Times. Retrieved from latimesblogs.latimes.com/lanow/2012/ 11 /prop-30-california-community-colleges-will-getfunding-boost-and-add-classes.html

Tarrow, S. (2011). Power in movement: Social movements and contentious politics. New York, NY: Cambridge University Press.

Wilde, M., \& Danielson, S. (2014). Fewer and better children: Race, class, religion, and birth control reform in America. American Journal of Sociology, 119(6), 1710-1760.

Wilde, M., \& Glassman, L. (2016). How complex religion can improve our understanding of American politics. Annual Review of Sociology, 42(2016), 407-425.

Wood, R. (2002). Faith in action: Religion, race, and democratic organizing in America. Chicago, IL: University of Chicago Press.

Wood, R., \& Fulton, B. (2015). A shared future: Faithbased organizing for racial equity and ethical democracy. Chicago, IL: University of Chicago Press.

Wuthnow, R. (2002). Beyond quiet influence? Possibilities for the protestant mainline. In R. Wuthnow \& J. H. Evans (Eds.), The quiet hand of god (pp. 381-404). Berkeley, CA: University of California.

Yukich, G. (2013). One family under god: Immigration politics and progressive religion in America. New York, NY: Oxford University Press.

\section{About the Author}

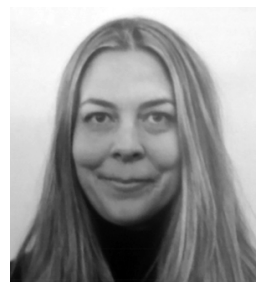

Rebecca Sager is an Associate Professor of Sociology at Loyola Marymount University. Her work looks at the intersection of religion, politics and social movements. She has published a number of articles on this topic. Her book Faith, politics, and power: The politics of faith-based initiatives (Oxford) looks at the role conservative Evangelical movement actors played in promoting the faith-based initiative at the state level. 